\title{
Köy Evlerinin İkinci Konuta Dönüşümü: Pelitköy Örneği (Burhaniye/Balıkesir)*
}

\section{Transformation of Village Housing into Second Homes: The Case of Pelitköy}

\author{
Serdar CEYLAN ${ }^{1}$ (D) Mehmet SOMUNCU² ${ }^{\circledR}$ \\ ${ }^{1}$ Kastamonu Üniversitesi, Fen Edebiyat Fakültesi, Coğrafya Bölümü, Kastamonu,Türkiye \\ ${ }^{2}$ Ankara Üniversitesi, Dil ve Tarih Coğrafya Fakültesi, Coğrafya Bölümü, Ankara, Türkiye
}

ORCID: S.C. 0000-0002-9599-5586; M.S. 0000-0001-8890-0537

\section{öz}

Araştırmanın amacı, Pelitköy yerleşmesi içerisindeki evlerin dışardan gelen kentli nüfusa satılmasının yerel halk üzerinde nasıl bir etki oluşturduğunu anlamaya çalışmaktır. Araştırmada nicel ve nitel yöntem birlikte kullanılmıştır. Yerel halktan 161 kişiye anket uygulanmıştır. Ayrıca yarı yapılandırılmış görüşme formları üzerinden 11 kişiyle de yüz yüze derinlemesine görüşmeler gerçekleştirilmiş; bu kişilerden 11'ine ilişkin veriler nitel bulgularda değerlendirilmiştir. Ankete katılanlar, basit tesadüfî (rastlantısal) örnekleme yöntemine; görüşme yapılan kişiler ise, amaçlı örneklem yöntemine göre belirlenmiştir. Anket verileri SPSS 16.0 programında, görüşme verileri ise MAXQDA 12 programında betimsel olarak analiz edilmiştir. Araştırma bulgularına göre, Pelitköy yerel halkının temel geçim kaynağı zeytin tarımıdır. Yerel halk ürettiği zeytinlerden zeytinyağı elde etmektedir. Köyde yaşayan Romanlar, zeytin arazisi olmayan düşük gelirli bir kesim olup; ikinci konutlarda temizlik ve bahçıvan işlerinde ve zeytin tarlalarında gündelikçi olarak çalışmaktadırlar. Son zamanlarda büyük kentlerden gelen insanların köy evlerini satın alması, alandaki konut piyasasını yükseltmiştir. Köyde evlenen gençler, köyde yüksek fiyattan ev kiralamakta ve satın almakta zorlandığı için kente göç etmeyi tercih etmektedir. Bu durum, kırsaldan kente olan göçü hızlandırmaktadır. Sonuç olarak, kentli nüfusun tatil ve dinlenme amaçlı olarak kırsal alanlara olan ilgisinin artması, yoksul yerel halk için hayat pahalılı̆ına neden olmakta ve yerel halkın yerinden olmasını hızlandırmaktadır.

Anahtar kelimeler: İkinci Konut Turizmi, Konut, Kırsal Dönüşüm, Pelitköy, Burhaniye

\section{ABSTRACT}

The aim of the study is to investigate the effect of selling houses within the Pelitköy settlement to the urban population on the local people. The research was carried via quantitative and qualitative research method. The survey was administrated to the local people (161). Moreover, in-depth face-to-interviews in a semi-structured form were conducted with 12 local individuals. The survey data was analyzed descriptively in SPSS 16.0 program, whereas interviews were analyzed descriptively in MAXQDA 12 program. According to the research findings, the main means of livelihood of the local people of Pelitköy is olive cultivation. Urban people, who have recently arrived in the village from big cities, increased the housing market by purchasing village houses. Young people married in the village prefer to emigrate to the city because of difficulties with renting and buying a house. This case accelerates migration from rural to urban areas. As a result, the increasing interest of the urban population to use rural areas for holiday and recreation purposes has increased the cost of living in the study area and accelerated the displacement of local people.

Keywords: Second-home Tourism, Housing, Rural Transformation, Pelitköy, Burhaniye

\footnotetext{
*Bu çalışma, Serdar CEYLAN'ın Ankara Üniversitesi Sosyal Bilimler Enstitüsü’nde Prof. Dr. Mehmet SOMUNCU danışmanlığında 2019 yılında tamamlanan 564618 numaralı doktora tezinden üretilmiştir.
}

Başvuru/Submitted: 16.05.2020 • Revizyon Talebi/Revision Requested: 28.10.2020 • Son Revizyon/Last Revision Received: 04.11 .2020 • Kabul/Accepted: 04.12.2020 • Online Yayın/Published Online: 22.12.2020

Sorumlu yazar/Corresponding author: SerdarCEYLAN / serdar_ceylan_51@hotmail.com Atıf/Citation: Ceylan, S., \& Somuncu, M. (2020). Köy evlerinin ikinci konuta dönüşümü: Pelitköy örneği (Burhaniye/Balıkesir). Cografya Dergisi, 41, $193-207$. https://doi.org/10.26650/JGEOG2020-0044 


\section{EXTENDED ABSTRACT}

Rural areas have become an increasingly considered topic (Bakırc1, 2007a: 23-24). Numerous settlements, such as villages, towns, and farms, have become attractive for tourism in terms of climatic conditions, natural features, landscape beauty, and rural lifestyle (Özgüç, 2007:129). An increase in the leisure and welfare level and advances in transportation and communication have led to the development of tourism in rural areas. Today, many people spend their holidays in rural areas (Rezavani, 2003; Keshavarznia et al., 2013: 181). Many villages in Turkey have ceased to be places of production and living and transformed into exclusively living places at the moment. Furthermore, an increase in the elderly and retired population in rural parts of Turkey has transformed rural areas from a production place to a living place (Tekeli, 2016, 138-140). Second homes used by people for holiday, rest, and renewal (Marjavaara, 2008: 7; Çimen, 2010: 10) are described as a private real estate investment that is utilized during holidays and outside of urban living conditions (Çubuk, 1981; Mizan, 1994: 9-10). Recently, researchers have focused on second home tourism that has affected rural societies economically, socially, and culturally. Therefore, second home tourism has become a topic explored by researchers from different departments, such as geography, tourism, planning, economics, and sociology (Coppock, 1977; Williams \& Hall, 2000; 2002; Asgary ed., 2011: 31). Unplanned development of second homes has caused many problems in the world, including economic, social, environmental, and cultural damages for rural societies (Keshavarznia ed., 2013: 181-182). Thus, second homes are regarded as an undesired change in rural areas (Müller, 2011). The rural population living second home tourism region experiences displacement, because of increasing housing prices. Therefore, traditional rural dwellings gradually turn into seasonal houses (Coppock, 1977; Hall and Müller, 2004b; Gülcan, 2013: 11).

The research was carried out using quantitative and qualitative research methods. The survey was administrated to the local people (161). Moreover, in-depth face-to-face interviews in a semi-structured form were performed with 27 local individuals. Only 12 interviews were evaluated in the qualitative findings. Participants in the survey were selected according to the simple random sampling method. Interviewed people were selected according to the purposive sampling method. The survey data was analyzed descriptively in SPSS 16.0 program, and interviews were analyzed descriptively in MAXQDA 12 program. Research questions: How does the sale of village houses to the people of the city have an economic and socio-cultural impact in the field of research? How do the locals perceive second-home tourism and second-home owners?

The research area located in the Aegean Region consists of two separate settlements, namely, the village and the seaside residential area. The main economic activity in the village that has 2,478 inhabitants is olive agriculture. The villagers produce olive oil from the olives they grow. Olive and agricultural land of the village is 2366 hectares, which represents $81.3 \%$ of the total land. The second-home settlement on the coast covers $13 \%$ of the study area. According to survey findings, the basic demographic characteristics of the participants are rural. They are generally married (80.1\%) and low educated (70.9\%). Moreover, they generally belong to the middle and upper age groups (48.4\%). The average age of the research group was calculated as $(\bar{X}=50.46)$. According to the survey, the participants are generally housewives (36\%), retired (19.9\%), farmers (15.5\%), and unemployed (11.2\%). 31.7\% of the research group makes a living directly from olive agriculture. The majority of the participants $(96.9 \%)$ thinks $(\bar{X}=4.02)$ that the economic value of village houses increased because of purchases made by outsiders who are living in cities. Moreover, $72.1 \%$ of them think $(\bar{X}=3.51)$ that second-home tourism in study area caused an increase in living costs. According to qualitative findings of the study, agricultural land located on the coast has passed from the villagers to the urban people and it is used for tourism and recreational purposes. Because of the second-home tourism, an increasing number of people arriving in the region has also increased the demand for village houses. The peasants sell their houses to the people of the city due to financial needs and high prices. This phenomenon has caused a rise in housing prices in the village. Roma people living in the research area also encounter difficulties in renting and purchasing houses. Consequently, young people marry and migrate from the village to cities. Put differently, the urban people who purchase village houses for holiday and recreation purposes have caused the displacement of local people from the village. 


\section{GÍRIŞ}

Pek çok ülkenin sosyal, ekonomik ve politik yeniden yapılanması kırsal mekânları tekrar tekrar şekillendirmekte (Woods, 2005) ve devletleri daha çok kırsal mekânlara odaklanmaya itmektedir (Gülümser vd., 2010: 135). Nitekim kırsal alan, gün geçtikçe daha fazla üzerinde durulan ve kabul gören bir kavram olmaktadır (Bakırcı, 2007a: 23-24). Çoğu kırsal alan herhangi bir şekilde ekonomik amaçla kullanılmakta ve coğrafi (mekânsal) görünümleri de beşeri faaliyetlerinden son derece etkilenmekte ve değiştirilmektedir. Kasaba, köy ve çiftlik gibi yerleşmeler; iklim koşulları, doğal özellikleri, manzara güzellikleri ve kırsal yaşam tarzı bakımından turizme çekici gelmektedir (Özgüç, 2007:129). Uryy'e (2015: 328) göre günümüzde kırsal alanlar, özellikle çeşitli türden koruma, spor ve hobilerle ilişkili olan çok sayıdaki heves ve sosyalliklerin yeri olmaktadır.

Tatil zamanlarında ve refah seviyelerindeki artışın yanı sıra ulaşım ve iletişimindeki gelişmeler, kırsal alanlarda turizmin gelişmesine yol açmaktadır. Günümüzde birçok insan tatillerini kırsal alanlarda yer alan seçkin çadırlar, ikinci konutlar, kiralık evler, moteller, hoteller ve yerleşmeye müsait diğer benzer alanlarda geçirmektedir (Rezavani, 2003; Keshavarznia vd., 2013: 181). Bu bağlamda ikinci konut alanlarının kentlerin çevresinde ya da hemen yakınlarında, o kentlerin büyüklüğüyle orantılı genişlikte ve fiziksel koşulların elverişliliğine göre geliştiği söylenebilir. $\mathrm{Bu}$ tatil evlerinin bulunduğu alan, kentlilerin mevsimlik, hafta sonu ya da zaman zaman dinlenmek amacıyla kullandıkları binalardan meydana gelmektedir. Bu alan, kırsal bir mekân üzerinde yer almış bulunmakta, hatta birçok yerde tamamen kır evlerinden meydana gelmektedir (Özgüç, 1984: 126-127). Nitekim günümüz Türkiye'sinde birçok köy, aynı anda bir üretim ve yaşama yeri olmaktan çıkarak, salt bir yaşam yeri olarak kullanılmaya başlanmıştır. $\mathrm{Bu}$ durum, birden fazla yolla gerçekleşmektedir. Bunlardan birincisi kırsal nüfus içinde emekli geliriyle geçinenlerin sayısının artmasıdır. Köyde yaşayan emeklilerin bir kısmı, yakın bir fabrikadan ya da maden ocağı işletmesinden emekli olmuş kimseler ile yurt dışından emekli olup köyüne geri dönmüş olanlardan oluşmaktadır. Bu emekliler köyde toprağ olan ve tarımla uğraşan kesimdir. Emeklilerin diğer bir kısmı ise, kışın kentte yazın kırda yaşayan emeklilerdir. Bu kimseler kentte çalışırken emekli olmuşlardır. Denize yakın bir yerde ya da bir yaylada yazlık ev (ikinci konut) edinmişlerdir. Tarımsal faaliyetlerle ilgili olmayan bu kesim, yazlıklarında yaşayarak yılın geri kalan aylarında kente geri dönmektedirler. Türkiye kırsal alanında yaşlı ve emekli nüfusunun artması köylerin "üretim yeri" olmaktan çok "yaşanan yer" olma niteliği kazanmasına neden olmaktadır. Nitekim emekli nüfusun önemli bir nüfusa ulaştığ1 değişik türde köy bulunmaktadır. Bu tür köylerde tarım yapılmamaktadır. Kıyı kesimindeki ve yaylalarda yazlık evler (ikinci konutlar) ve turistik tesisler yapılmaktadır. $\mathrm{Bu}$ yerleşmeler, kış aylarında boşalmaktadır. Kırsal alanlardaki bu yazlık evler (ikinci konutlar), kent orta sınıflarının dinlence talebini ifade etmektedir. Bu talebin tarihi, kırsal alanlardaki bağ evlerine kadar uzanan tarihi bir kökeni de bulunmaktadır (Tekeli, 2016, 138-140).

\section{LITERATÜR: KIRSAL ALANLARDA İKINNCI KONUTLAR}

İnsanların genellikle tatil, dinlenme ve yenilenme amaçlı olarak yılın belirli bir döneminde kullandığı ikinci konutlar (Marjavaara, 2008: 7; Çimen, 2010: 10), tatil zamanlarında yararlanılan ve kentsel yaşam koşullarının dışında yapılan bir özel emlak yatırımı (Çubuk, 1981; Mizan, 1994: 9-10) olarak tanımlanmaktadır. Marjavaara'ya (2008: 7) göre ise ikinci konut, sahipleri ya da başka birileri tarafından geçici ziyaret için kullanılan bir mesken olup, kullanıcının kalıcı olmayan yeridir. İkinci konutlar; başka bir yerde ikamet eden kullanıcıları tarafindan satın alma veya kiralama yoluyla yılın belirli dönemlerinde rekreatif amaçlı olarak kullanılan, fiziksel çekiciliği yüksek mekânlarda (göl, deniz kıyısı vb.) inşa edilmiş, turizm sektörü ile bütünleşmiş ve bir emlak yatırımı özelliği gösteren sabit bir mülk (Görgülü \& Manisa, 2008; Gökeniz vd., 2010: 848) olarak da tanımlanabilmektedir. Birol-Özerk'e göre ise (2012: 29) ikinci konutlar; y1lın belirli dönemlerinde genellikle tatil amacıyla kullanılmak üzere inşa edilen, kullanıcısının kent yaşantısının artan sorunlarından uzaklaşmak, dinlenmek, yenilenmek gibi amaçlarla görece kısa süreli olarak kullanılmakta olan bir yapı tipidir. Nitekim yapılan birçok araştırmada da ikinci konutlar, genel olarak boş zaman tüketiminin bir bölümü olarak görülmüștür (Marsden, 1969: 5773; Hoogendoorn \& Visser, 2004: 106).

İkinci konut turizminin kırsal alanlarda yaşayan toplum üzerindeki sosyal, ekonomik ve kültürel etkiler göstermesi, araştırmacıları bu konu üzerine yoğunlaştırmıştır. Bu nedenle, "ikinci konut turizmi, son otuz yıldır coğrafya, turizm, planlama, ekonomi ve sosyoloji gibi farklı alanlardaki araştırmacılar tarafindan araştırılan bir konu olmuştur" (Coppock, 1977; Williams ve Hall, 2000; 2002; Asgary vd., 2011: 31). Müller (2002), "Kırsal Kesimi Yeniden Keşfetmek: Güney İsveç'teki Alman İkinci Konut Sahipleri”; Gallent vd.'nin (2003), “Bir Ifsane Mi? Kirsal Wales'te İkinci Konutlar"; Cottyn (2011), 
"İkinci Konut Gelişiminin Mekânsal ve Sosyokültürel Etkileri: Franschhoek (Güney Afrika) Üzerine Araştırma"; Rye ve Berg (2011) ise, "İkinci Konut Olgusu ve Norveç Kırsalı" konulu araştırmalar yapmışlardır.

Kırsal mekânlardaki ikinci konutların en büyük çekicilikleri arasında, günlük kent yaşamının telaşlı doğasından uzaklaşma arzusu yatmaktadır (Hall ve Müller, 2004b). Bu sebeplerden dolayı birçok ikinci konut, tipik olarak kıyı veya kırsal alanları oluşturan kırsal bölgelerde yer almaktadır (Willams, 2010: 9). 1974 yılında Londra'da yapılan İkinci Konut Sempozyumu'nda Avrupa ve Kuzey Amerika'da ikinci konutların yer seçiminin üç önemli tercihe bağlı olduğu vurgulanmıştır (Karaaslan vd., 2005: 3-4; Bakırc1, 2007b: 22): (i) Büyük kent merkezlerine kolay erişim sağlayacak kırsal alanlar (ii) kıyı alanları (iii) çekici ve iyi manzarası olan yüksek alanlar.

Kırsal rekreasyon faaliyetlerinin ve ziyaretçi sayısının kırsal alanların taşıma kapasitesinin üzerine çıkması, kırsal alanların kentlerdeki gibi çeşitli sorunlarla karşı karşıya kalmasına neden olmaktadır (Özgüç, 1984: 126). İkinci konutlardaki plansız gelişimi hem dünyada hem de Türkiye'de birçok probleme neden olmaktadır. Sonuç olarak, bu durum kırsal toplumlar için ekonomik, sosyal, çevresel ve kültürel zararlarla sonuçlanmaktadır. Örneğin İran'ın kentsel gelişimi, insanları tatil için kırsal alanlarda ikinci konutlar inşa etmeye itmiştir. Genel olarak ikinci konutlar, ülkedeki büyümesini hızlandırarak devam ettirmektedir. Kırsal alanlarda ikinci konutların gelişmesi hakkında İran'da yapılan araştırmalar yoğunlaşmış durumdadır. Bu konutların sayısı tam olarak henüz belirlenememiş olsa da yapılan çalışmalar ve gözlemler, ikinci konut inşasında bir artışın devam edeceği öngörülmektedir. Bu eğilimin özellikle uygun turizm firsatları, iyi bir iklimi, orman, dağ ve deniz gibi manzaraları olan ülkenin kuzey bölgelerine kayacağ1 düşünülmektedir (Keshavarznia vd., 2013: 181-182). Britanya bağlamında düşünüldüğünde ise, ikinci konutların toplum içinde birçok problem oluşturduğu görülmektedir. Konut kıtllı̆̆, kırsal alanlardan dışa olan göçün hızlanması, yerinden etme, ikinci konut sahipleri ve yerel halk arasında kaçınılmaz bir şekilde beliren çatışma ve sezonluk etkilerden dolayı ortaya çıkan suç olayları bu problemlerden dikkat çeken bazılarıdır (Müller ve Hoogendoorn, 2013; Hoogendoorn ve Visser, 2015: 2). Bu yüzden ikinci konutlar, kırsal alanlarda istenmeyen bir değişim olarak görülmektedir (Müller, 2011). Özellikle Britanya'da ikinci konutlar, kırsal için artan bir şekilde tehdit olarak görülmektedir (Müller ve Hoogendoorn, 2013: 353). İkinci konut sahiplerinden dolayı konut fiyatlarının artması, kalıcı kırsal nüfusun yerinden edilmesi sorununu gündeme getirmekte ve bu durum sonucunda, genç ailelerin bir konut satın alamamasına neden olmaktadır. $\mathrm{Bu}$ yüzden geleneksel kırsal konutlar (köy meskenleri) zamanla sezonluk konutlara dönüşmektedir (Coppock, 1977; Hall ve Müller, 2004b; Gülcan, 2013: 11).

\section{AMAÇ VE YÖNTEM}

Tatil ve dinlenme amaçlı olarak, kentli nüfusun kırsal alanlar üzerinde artan talepleri olmaktadır. Bu araştırmanın amacı ise, Pelitköy yerleşmesi içerisindeki evlerin dışardan gelen kentli nüfusa satılmasının yerel halk üzerinde nasıl bir etki oluşturduğunu anlamaya çalışmaktır. Araştırmada hem nitel hem de nicel verilerin birlikte toplandığı, ayrı ayrı analiz edildiği ve sonuç kısmında birlikte yorumlandığı "yakınsayan

paralel karma yöntemi”' kullanılmıştır. Bu yöntem ile nicel ve nitel verilerin birbirini desteklemesi, doğruluğunun kontrol etmesi, bulguların bütünleştirilmesini sağlaması amaçlanmıştır. Pelitköy yerel halkından 161 kişiye anket uygulanmış; katılımcılar, basit tesadüfî (rastlantısal) örnekleme yöntemiyle belirlenmiştir. Katılımcıların ikinci konut turizmi ve ikinci konut sahipleri (yazlıkçılar) hakkındaki düşünceleri ve memnuniyet düzeyleri araştırmada ölçülmek istenmiştir. Buna göre araştırma grubuna belirli yargılar yöneltilmiş ve bu yargıya katılıp katılmadıkları 5'li likert ölçeği ile kesinlikle katılmıyorum (1) ile kesinlikle katılıyorum (5) arasında derecelendirmeleri istenmiştir. Ayrıca yarı yapılandırılmış görüşme formları üzerinden 27 kişiyle de yüz yüze derinlemesine (30-50 dk.) görüşmeler gerçekleştirilmiş; bu kişilerden 11'ine ilişkin veriler nitel bulgularda değerlendirilmiştir. Görüşme sorularının tam olarak yapılandırılmasından kaçınılmış; görüşme soruları üzerinden katılımcı ile derinlemesine görüşmenin yapılması hedeflenmiş; görüşme esnasında konunun açılması için yer yer sondaj sorular sorulmuştur. Görüşme yapılan kişiler (Pelitköy yerel halkı), amaçlı örneklem yöntemine göre belirlenmiştir. Sahada ses kaydına alınan görüşmeler, daha sonra Microsoft Word programına yazılarak MAXQDA 12 programına aktarılmıștır. Programın sol ara yüzünde oluşturulan kategoriler altına, să̆ ara yüzdeki görüşme metninden alıntılama ve kodlamalar yapılmıştır. Kodlamalar, katılımcı ifadelerinin koda dönüştürülmesi (açık kod sistemi) ile oluşturulmuştur. Araştırma alanının nüfus ve arazi kullanım verileri ile harita ve fotoğrafları çalışmanın ikinci veri kaynaklarını oluşturmaktadır. Araştırma soruları: Köy evlerinin dışardan gelen kent halkına satılması araştırma alanında ekonomik ve sosyokültürel bakımdan nasıl bir etki oluşturmaktadır? Pelitköy yerel halkı, ikinci konut turizmi ve ikinci konut sahipleri hakkındaki nasıl bir düşünceye sahiptir? 
4. ARAŞTIRMA ALANININ LOKASYONU VE GENEL DURUMU

Araştırma alanı olan Pelitköy, Ege Bölgesi'nde yer almakta olup Asıl Ege Bölümü’nün Edremit Yöresi sınırları içerisinde kalmaktadır (Şekil 1). İdari olarak ise, Balıkesir İli'nin Burhaniye
İlçesi'ne bağlı bir mahalledir. Pelitköy iki ayrı yerleşim biriminden oluşmaktadır: Köy yerleşim alanı ve sahilde yer alan ikinci konut yerleşim alanı (Şekil 2). Köy yerleşim alanı, deniz kıyısından yaklaşık $4 \mathrm{~km}$ içeride yer almaktadır (Foto 1). Pelitköy'ün Burhaniye ilçe merkezine olan uzakllğı ise yaklaşık 14 km'dir.

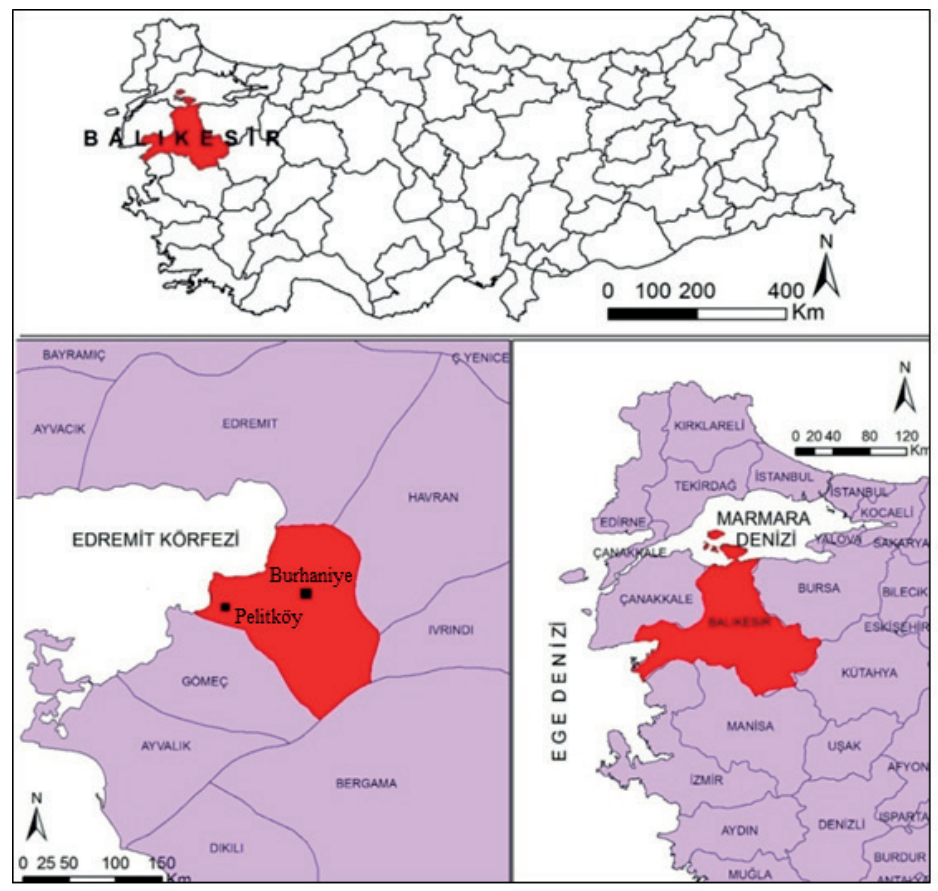

Şekil 1: Araştırma Sahasının Lokasyonu.

Figure 1: Location map of research area.

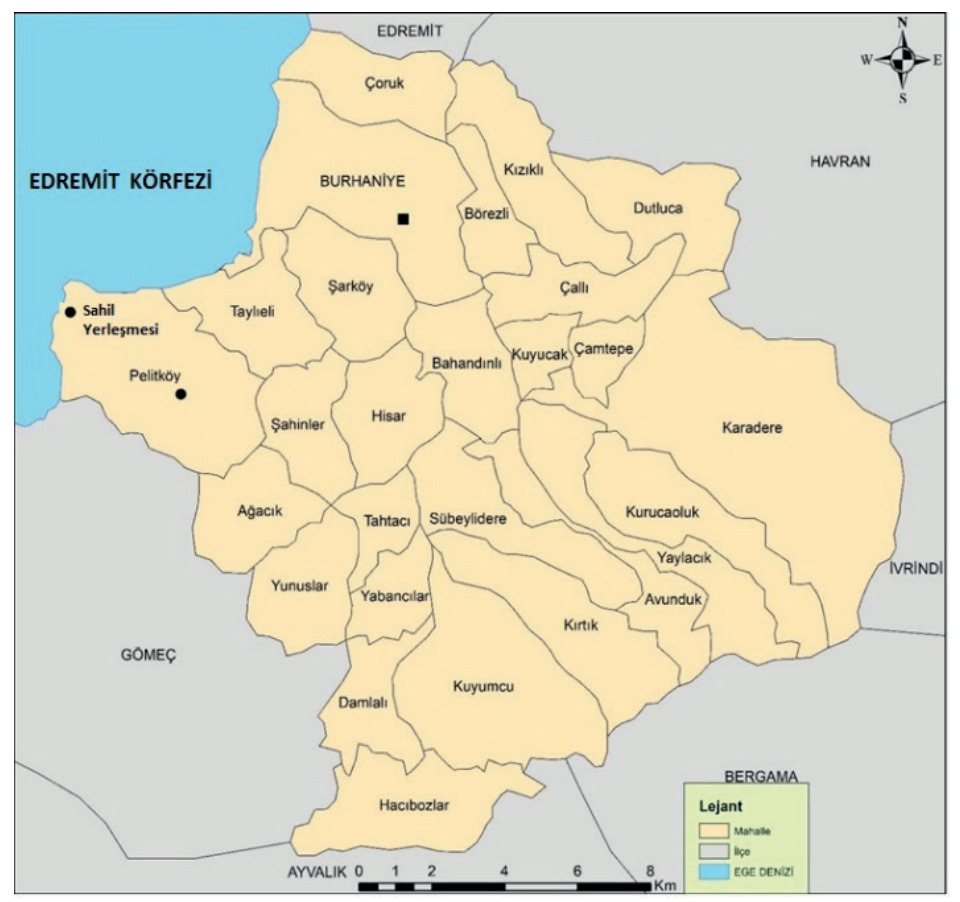

Şekil 2: Burhaniye İlçesinin Mahalleri.

Figure 2: Neighborhoods of Burhaniye district. 


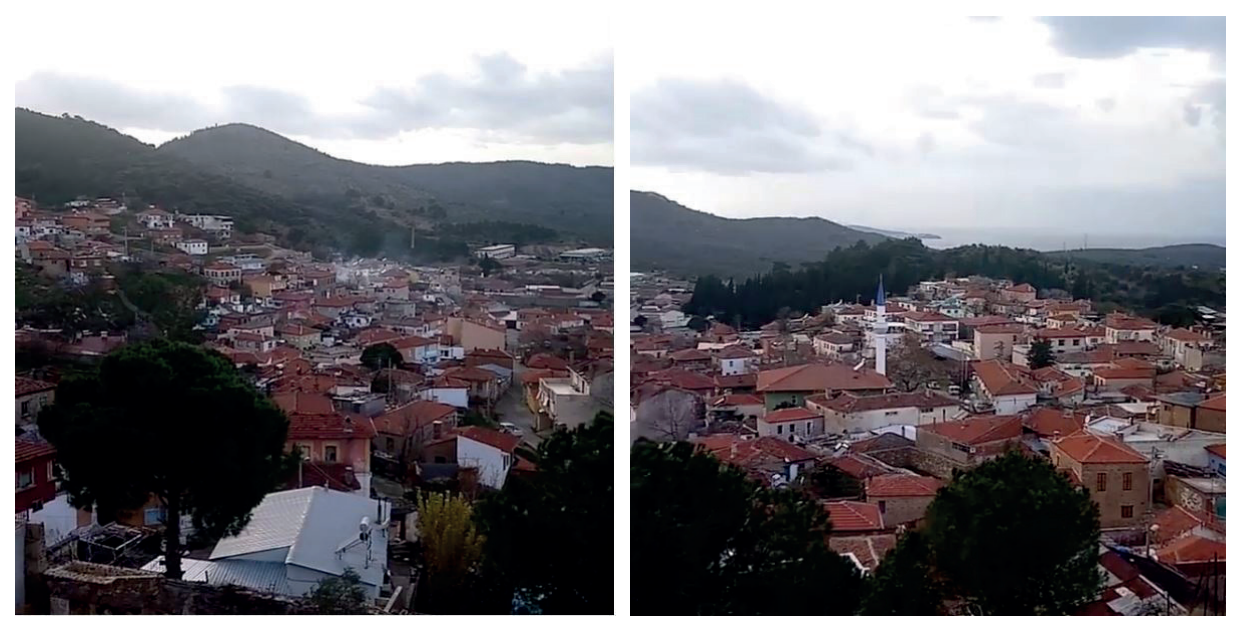

Foto 1: Pelitköy (Köy) Yerleşmesinden Genel Görünümler.

Photo 1: General View from Pelitköy settlement.

Pelitköy, Cumhuriyet başlarında bir köy yerleşmesi iken, 1972 yılında belediye örgütüne (Pelitköy Belediyesi) kavuşarak belde yerleşmesi olmuştur. Uzun yıllar belde statüsünde kalan bu yerleşme, Balıkesir ilinin (6360 Sayılı Büyükşehir Kanunu kapsamında) 2014 yılında büyükşehir olmasıyla birlikte Burhaniye ilçesine bağlı bir mahalle (Pelitköy Mahallesi) statüsüne dönüştürülmüştür.

İzmir-Çanakkale karayolunun (D550) araştırma alanı içerisinden geçmesi ve Edremit Koca Seyit Havalimanı'nın Pelitköy’e yaklaşık 18 km'lik bir uzaklıkta yer alması araştırma sahasının bölgedeki büyük nüfuslu kentler için erişilebilir bir noktada yer almasına imkân vermektedir. Bu durum, bölgeye olan insan hareketliliğini artırmakta ve ikinci konut turizmine doğru büyük kentlerden daha fazla yönelim olmaktadır.

\subsection{Araştırma Alanında Arazi Kullanımı ve Sosyoekonomik Yapısı}

Araştırma alanının toplam arazi varlığı, 2910 hektar (29.109.157 $\mathrm{m}^{2}$ )'dır. Alandaki arazi kullanım durumuna baktığımızda, en yoğun arazi kullanımının (\%81,3) tarıma (tarım/zeytincilik) ayrılmış olduğu görülmektedir. Tarım alanlarından sonra alandaki en yoğun arazi kullanımı \%13

Tablo 1: Pelitköy'de Arazi Kullanımı.

Table 1: Land use in Pelitköy where is research area.

\begin{tabular}{lrrr}
\hline Arazi Dağılımı & $\mathbf{m}^{2}$ & Hektar & $\%$ \\
\hline Köy içi yerleşim alanı & 1.243 .891 & 124,3 & 4,3 \\
Sahil yerleşim alanı & 3.804 .431 & 380,4 & 13 \\
Zeytinlik ve tarım alanı & 23.666 .935 & 2366 & 81,3 \\
Orman & 393.900 & 39,3 & 1,4 \\
Toplam & 29.109 .157 & 2910 & 100 \\
\hline
\end{tabular}

Kaynak: Burhaniye Belediyesi (Erişim: 01.08.2017). oranıyla sahil yerleşim alanıdır. Sahildeki bu yerleşim alanı, ikinci konutların yer aldığı site yerleşmeleridir (Tablo 1).

Tablo 1'deki arazi kullanım verilerinden de görüldüğü üzere, Pelitköy halkı temelde zeytin tarımı ile uğraşmakta ve ürettiği zeytinlerden zeytinyağı elde etmektedir. Diğer bir ifadeyle, yerel halkın temel ekonomik faaliyeti zeytin tarımına dayanmaktadır. Zeytin ağaçlarından elde edilen zeytinler köy içerisindeki zeytinyağı tesislerinde işlenmektedir. Pelitköy içerisinde bir tanesi Tariş işletmesinde olan toplam 5 adet zeytinyağı tesisi bulunmaktadır. Diğer bir ifadeyle, Pelitköy'de temel ekonomik faaliyet zeytin tarımıdır. Ancak Pelitköy'de yaşayan Romanların tarım arazileri bulunmamakta; Romanlar kış döneminde zeytin bahçelerinde gündelikçi (yevmiyeci) olarak, yaz sezonunda ise sahildeki ikinci konut sitelerinde temizlik, bekçilik ve bahçıvanlık gibi vasıfsız işlerde sezonluk olarak çalışmaktadır. Sosyal güvenceleri olmadan sezonluk olarak tarımda ve ikinci konut sitelerinde çalışan bu kesim, Pelitköy’ün yoksul sınıfını oluşturmaktadır.

Pelitköy halkının bir kısmı Cumhuriyet dönemi başlarında yapılan nüfus mübadelesi ile Yunanistan'dan gelmiştir. Pelitköy’e yerleşen bu göçmenler "Trakya göçmeni”, "muhacir”, "adalı” gibi isimlerle bilinmektedir. Pelitköy’de yaşayan yaşlıların (60 yaş üstï) bir kısmı, Cumhuriyet döneminde Pelitköy'e gelen bu göçmenlerin çocukları ve torunlarıdır. İdari bakımdan yerleşmenin statüsü değişirken, nüfusu da süreç içerisinde değişiklik göstermiştir. Pelitköy 2007-2012 yılları arasında nüfusu, Türkiye kırsal alanlarının genel karakteristiğini yansıtacak şekilde, giderek azaldığı görülmektedir (Tablo 2). Pelitköy (yerel halkı) nüfusunun 2018 yılında toplam 2478 kişi olduğu tespit edilmiştir.

Araştırma alanından Burhaniye, Edremit ve İzmir gibi çevredeki kentlere olan göçler, nüfusun Pelitköy’de azalmasına 
Tablo 2: Burhaniye ve Pelitköy'ün Nüfus Gelişimi.

Table 2: Developing of population in Burhaniye and Pelitköy.

\begin{tabular}{|c|c|c|c|c|c|c|c|c|c|c|c|}
\hline Yerleşme & 2007 & 2008 & 2009 & 2010 & 2011 & 2012 & 2013* & $2014^{*}$ & 2015* & 2016* & $2017 *$ \\
\hline Burhaniye İlçe Merkezi & 36.696 & 37.415 & 38.156 & 39.840 & 40.824 & 41.918 & 52.674 & 57.554 & 57.090 & 57.800 & 58.775 \\
\hline Pelitköy & 2.545 & 2.643 & 2.278 & 2.186 & 2.105 & 2.034 & - & - & - & - & - \\
\hline
\end{tabular}

Kaynak: TÜiK, 2017b. *6360 Sayılı Büyükşehir Yasası ile birlikte köy/mahalle nüfus verileri TÜiK tarafından Burhaniye İlçe Merkezi (Burhaniye Belediyesi) içerisinde verilmektedir.

neden olmaktadır. Pelitköy’ün gençleri genelde Burhaniye ilçe merkezine ve ilçeye bağlı İskele, Ören ve Öğretmenler Mahallesi'ne göç etmektedir. Pelitköy'ün gençleri bu yerleşmelerde iş bularak yaşamlarını sürdürmektedir. Pelitköy'ün yüksek eğitim almış gençleri, İzmir ve Balıkesir başta olmak üzere çevre illerde doktor, öğretmen ve memur gibi değişik kamu görevlerinde çalışmaktadırlar.

Daha önce Pelitköy (belediye örgütüne sahip) bir belde yerleşmesi olması nedeniyle Pelitköy'de var olan birçok hizmet fonksiyonunun günümüzde de devam ettiği görülmektedir. Nitekim Pelitköy'de sağlık ocağı, eczane, PTT şubesi, sendika şubesi, demir doğrama atölyesi, zeytinyağı satış dükkânı, 3 berber, 5 kahvehane ve 5 bakkal işletmesi bulunmaktadır.

Pelitköy Belediyesi, yerleşmenin sosyo-ekonomik ve sosyokültürel olarak gelişmesinde önemli rol oynamıştır. Araştırma alanı sahilinde yer alan ikinci konut sahipleri, belediye hizmetleri için Pelitköy Belediyesi ile zorunlu ve kaçınılmaz bir ilişki içerisinde olmuşlardır. İkinci konut sahiplerinin emlak vergisi, su tahsilatı, altyapı ve üstyapıda ihtiyaç duyduğu bakım onarım talepleri yıllarca Pelitköy Belediyesi tarafından üstlenilmiştir. İkinci konut sahiplerinin Pelitköy Belediyesi ile olan bu ilişkisi, yerel halk ile daha sıkı temas kurmasına neden olmuştur. Nitekim Pelitköy Belediyesi ile birlikte birçok hizmet fonksiyonu (sağllk ocağı, eczane, PTT şubesi, sendika şubesi, demir doğrama atölyesi, zeytinyağı satış dükkânı, 3 berber, 5 kahvehane ve 5 bakkal işletmesi) Pelitköy'ün belde olmasıyla birlikte ortaya çıkmıştır. Ancak Pelitköy Belediyesi'nin kapanması, belediyenin hizmetler fonksiyonunda çalışanların (memur, işçi) ve yerel halkın çevredeki diğer yerleşmelere (İskele, Ören ve Öğretmenler Mahallesi, Burhaniye ilçe merkezi) göçmesine neden olmuştur. Bu durum, Pelitköy'ün giderek gerilemesine ve devam eden çeşitli hizmetlerin (sağlık ocağı, PTT vb.) de kapanabilmesine neden olabilecektir.

\section{BULGULAR}

\subsection{Ankete İlişkin Analiz ve Bulgular}

Araştırmaya katılan Pelitköy halkının temel demografik özelliklerine bakıldığında, katılımcıların \%60,2'si erkeklerden \%39,8'i ise kadınlardan oluşmaktadır. Yerel halkın genel olarak kırsal yaşam kültürünün etkisinde olması, yani toplumsal cinsiyet baskısının yoğun olması, araştırma grubunda cinsiyetin eşit dağılımına engel olmuştur. Zira hanelerde yapılan görüşmelerde, kadınların kendilerini geri plana iterek, eşinin soruları yanıtlamasını istediği, çalışma boyunca karşılaşılan sorunlardan biri olarak öne çıkmıştır. Demografik verilerden bir diğeri medeni durumdur. Buna göre araştırma grubunun $\% 80,1$ ' $\mathrm{i}$ evli, \%13'ü bekâr, \%6,2'si eşini kaybetmiş ve \%0,6'sı boşanmıştır (Tablo 3). Eğitim durumlarına bakıldığında ise, Pelitköy yerel halkının \%11,2'si okuryazar değilken, \%7,5'i diplomasız

Tablo 3: Pelitköy Yerel Halkının Temel Demografik Özellikleri. Table 3: Basic demographic features of local people in the study area.

\begin{tabular}{|c|c|c|c|}
\hline Değişken & & $\mathbf{N}$ & (\%) \\
\hline \multirow[t]{2}{*}{ Cinsiyet } & Erkek & 97 & 60,2 \\
\hline & Kadın & 64 & 39,8 \\
\hline \multirow[t]{4}{*}{ Medeni Durum } & Bekâr & 21 & 13,0 \\
\hline & Evli & 129 & 80,1 \\
\hline & Eşi Ölmüş & 10 & 6,2 \\
\hline & Boşanmış & 1 & 0,6 \\
\hline \multirow[t]{8}{*}{ Eğitim } & Okuryazar olmayan & 18 & 11,2 \\
\hline & Okuryazar & 12 & 7,5 \\
\hline & İlkokul & 84 & 52,2 \\
\hline & Ortaokul & 27 & 16,8 \\
\hline & Lise & 14 & 8,7 \\
\hline & Ön lisans & 2 & 1,2 \\
\hline & Lisans & 3 & 1,9 \\
\hline & Lisansüstü & 1 & 0,6 \\
\hline \multirow[t]{6}{*}{ Yaş } & 18-24 Yaş & 13 & 8,1 \\
\hline & 25-34 Yaş & 21 & 13,0 \\
\hline & 35-44 Yaş & 28 & 17,4 \\
\hline & 45-54 Yaş & 2 & 13,0 \\
\hline & 55-64 Yaş & 39 & 24,2 \\
\hline & $65+$ Yaş & 39 & 24,2 \\
\hline \multirow[t]{8}{*}{ İş Durumu } & Emekli & 32 & 19,9 \\
\hline & Ev kadını & 58 & 36,0 \\
\hline & Çiftçi & 25 & 15,5 \\
\hline & Esnaf & 20 & 12,4 \\
\hline & Kamu çalışanı & 4 & 2,5 \\
\hline & Özel sektörde çalışan & 3 & 1,9 \\
\hline & Öğrenci & 1 & 0,6 \\
\hline & Çalışmayan, İşsiz & 18 & 11,2 \\
\hline \multirow[t]{4}{*}{ Hane Aylık Gelir } & $0-1000 \mathrm{TL}$ & 80 & 49,7 \\
\hline & 1001-1400 TL & 33 & 20,5 \\
\hline & 1401-2000 TL & 46 & 28,6 \\
\hline & 2001-3000 TL & 2 & 1,2 \\
\hline Toplam & & 161 & 100,0 \\
\hline
\end{tabular}


okuryazar, \%52,2'si ilkokul, \%16,8'i ortaokul, \%8,7'si lise, $\% 1,2$ 'si ön lisans, \%1,9'u lisans ve \%0,6’s1 lisansüstü eğitim almıştır. Eğitim seviyesinin ikinci konut sahiplerine oranla çok düşük olduğu görülmektedir (Tablo 3). Demografik verilerde sunulan bir diğer bulgu yaş aralığıdır. Araştırma grubunun \%8,1'i 18-24 yaş aralığındayken, \%13'ü 25-34 yaş, \%17,4'ü 3544 yaş, \%13'ü 45-54 yaş, \%24,2'si 55-64 yaş ve \%24,2'si 65 ve üzeri yaş aralığındadır. Araştırma grubunun yaş ortalaması ise $(\bar{X}=50,46)$ olarak hesaplanmıştır. Genel olarak bakıldığında, kırsal toplumsal yapının karakteristiği ile uygun olarak, genç nüfus oranının düşük olduğu görülmektedir (Tablo 3).

İş durumuna ait bulgular da demografik verilerde sunulmaktadır. Buna göre araştırma grubunun \%19,9'u emekli, \%36'sı ev kadını, \%15,5'i çiftçi, \%12,4'ü esnaf, \%2,5’i kamu çalışanı, \%1,9'u özel sektör çalışanı, \%0,6'sı öğrenci ve \%11,2'si işsiz, çalışmayanlardan oluşmaktadır (Tablo 3). Genel olarak yerel halkın yaklaşık 1/3'ünün (çiftçi, esnaf, kamu çalışanı, özel çalışan) sürekli iş olanaklarına sahip olduğu görülmektedir. Bunun doğal yansıması ise hane aylık gelir durumunda belirmektedir. Araştırma grubunun \%49,7'si 1000 TL altında hane aylık gelirine sahipken, \%20,5'i 1001-1400 TL, \%28,6's1 1401-2000 TL ve \%1,2'si 2001-3000 TL arasında geliri bulunmaktadır. Başka bir deyişle araştırma grubunun \%70,2'si, dönemin asgari ücreti olan 1408 TL'nin altında gelire sahiptir (Tablo 3).

Türkiye'de 1980'li ve 1990'lı yıllarda tarımda yaşanan neoliberal dönüşümün en önemli etkisi tarım sektöründen kopuş olmuştur. Zira kırsal kesimde tarım, artık gelirin kaynağı olmaktan çıkmış ve insanlar geçinebilmek için alternatiflere yönelmiştir. Tablo 4 incelendiğinde, araştırma grubunun \%31,7'sinin geliri doğrudan tarımdan yani zeytinciliktenken, \%26,7'sinin geliri emekli maaşı, \%12,4’ünün geliri ise esnaf gelirine sahip olduğu görülmektedir. Bunun yanında katılımcıların \%17,4’ünün zeytin bahçelerine ve ikinci konutlara gündelikçi olarak gittikleri ve gelirini bu yolla edindikleri, \%9,3'ünün maaş, \%1,9'unun ise yaşlılık maaşını gelirinin kaynağı olarak belirttiği görülmektedir (Tablo 4). Araştırma alanında hane geliri emeklilik maaşı, esnaf geliri ve maaş geliri olanlar, aynı zamanda geçim türü amaçlı olarak (kendi ihtiyaçlarını karşılayacak miktarda) zeytincilikle de uğraşmaktadırlar.

Tablo 4: Pelitköy Yerel Halkının Gelir Durumuna İlişkin Bilgiler. Table 4: Income level of local people in the study area.

\begin{tabular}{lcc}
\hline & $\mathbf{N}$ & $\mathbf{( \% )}$ \\
\hline Gelir Yok & 1 & 0,6 \\
Zeytincilik & 51 & 31,7 \\
Emekli Maaşı & 43 & 26,7 \\
Esnaf & 20 & 12,4 \\
Maaş & 15 & 9,3 \\
Yaşlılık Maaşı & 3 & 1,9 \\
Gündelik-Yevmiye & 28 & 17,4 \\
Toplam & 161 & 100,0 \\
\hline
\end{tabular}

Kırsal alanlardaki mekânsal dönüşümün yerel halk üzerindeki sosyo-ekonomik, kültürel etkileri hakkında fikir edinilebilmek için, araştırma grubuna bir takım ifadeler yöneltilmiş ve katılıp katılmadıklarını 5'li likert ölçeği ile kesinlikle katılmıyorum (1) ile kesinlikle katıliyorum (5) arasında derecelendirmeleri istenmiştir (Tablo 5).

Tablo 5: Pelitköy Yerel Halkının Ikinci Konut Turizmi Ile İlgili Memnuniyet Düzeyleri. Table 5: Satisfaction levels of local people regarding second home tourism.

\begin{tabular}{|c|c|c|c|c|c|c|}
\hline \multirow[t]{2}{*}{ Ifadeler } & $\begin{array}{c}\text { Kesinlikle } \\
\text { Katılmıyorum } \\
\text { (1) }\end{array}$ & $\begin{array}{l}\text { Katılmıyorum } \\
(2)\end{array}$ & $\begin{array}{c}\text { Kararsızım } \\
\text { (3) }\end{array}$ & $\begin{array}{l}\text { Katılıyorum } \\
(4)\end{array}$ & $\begin{array}{c}\text { Kesinlikle } \\
\text { Katılıyorum } \\
\text { (5) }\end{array}$ & \multirow{2}{*}{$\begin{array}{l}\text { Ortalama } \\
\qquad(\overline{\mathrm{X}})\end{array}$} \\
\hline & $(\%)$ & (\%) & (\%) & (\%) & (\%) & \\
\hline Pelitköy'e gelen yazlıkçılardan memnunum & 4,3 & 19,9 & 11,2 & 61,5 & 3,1 & 3,39 \\
\hline $\begin{array}{l}\text { Sahildeki yazlıkçılar bizimle sohbet edip } \\
\text { kaynaşmaktadırlar }\end{array}$ & 1,2 & 23,0 & 12,4 & 60,9 & 2,5 & 3,40 \\
\hline $\begin{array}{l}\text { Dışarıdan gelen yabancıların Pelitköy'den köy evi } \\
\text { satın alıp yazın köyde kalmasından memnunum }\end{array}$ & 2,5 & 20,5 & 7,5 & 68,9 & 0,6 & 3,45 \\
\hline $\begin{array}{l}\text { Yazlıkçılar gelenek ve göreneğimizi } \\
\text { değiştirmektedir }\end{array}$ & 1,9 & 69,6 & 3,7 & 24,2 & 0,6 & 2,52 \\
\hline $\begin{array}{l}\text { Sahildeki yazlık evler köyde geçim sıkıntısına } \\
\text { neden olmaktadır }\end{array}$ & 2,5 & 74,5 & 5,0 & 18,0 & 0 & 2,39 \\
\hline Sahildeki yazlık evler burada hayatı pahalandırdı & 1,2 & 24,2 & 2,5 & 66,5 & 5,6 & 3,51 \\
\hline $\begin{array}{l}\text { Köydeki evlerin yabancılara satılmasını doğru } \\
\text { buluyorum }\end{array}$ & 3,1 & 32,3 & 6,8 & 55,9 & 1,9 & 3,21 \\
\hline Yazlıkçılardan dolayı köy evlerimizin değeri arttı & 0 & 2,5 & 0,6 & 88,8 & 8,1 & 4,02 \\
\hline $\begin{array}{l}\text { Yazlıkçıları köyümüze gelen misafirler olarak } \\
\text { görüyoruz }\end{array}$ & 1,9 & 20,5 & 3,1 & 71,4 & 3,1 & 3,53 \\
\hline $\begin{array}{l}\text { Yazlıkçılar köyde ve aile içinde tartışmalara neden } \\
\text { olmaktadır }\end{array}$ & 8,1 & 83,9 & 3,7 & 4,3 & 0 & 2,04 \\
\hline
\end{tabular}


- "Pelitköy'e gelen ikinci konut sahiplerinden (yazlıkçllardan) memnunum" ifadesine $(\bar{X}=3,39)$ katılımciların \%64,6'sının memnun olduğu, \%24,2'sinin memnun olmadığı, \%11,2'sinin ise kararsız olduğu görülmektedir (Tablo 5). İkinci konut sahipleri bizimle sohbet edip kaynaşmaktadır ifadesine $(\bar{X}=3,40)$ katılımcıların \%63,4'ü katılmıştır. Katılımcıların \%24,2’si ise bu ifadeye katılmamıştır (Tablo 5).

- “Dişarıdan gelen yabancıların Pelitköy'den köy evi satın alıp yazın Pelitköy'de kalmasindan memnunum" ifadesine $(\bar{X}=3,45)$ katılanların \%69,5 katılmayanların ise \%23, kararsızların ise \%7,5 olduğu görülmektedir. "Köydeki evlerin yabancılara satılmasını doğru buluyorum" ifadesine $\quad(\bar{X}=3,21) \quad$ katılanların $\% 57,8$ olduğu, katılmayanların ise \%35,4 olduğu görülmektedir. Köy evlerinin dişarıdan gelenler tarafindan satın alınmasıyla evlerin değgerinin arttı̆̆ını belirtenler $(\bar{X}=4,02)$ yüksek bir oran $(\% 96,9)$ göstermektedir (Tablo 5). Katılımcıların büyük bir kısmı $(\% 74,5)$, köylerine gelen yazlıkçıları misafir olarak gördüklerini $(\bar{X}=3,53)$ belirtmektedirler (Tablo 5). Tüm bu ifadeler birlikte düşünüldügünnde, katılımcıların köyden ev alıp yaz sezonunda köyde kalan kişiler hakkında ve köy evlerinin bu kişilere satılması hakkında genel bir çoğunluğun olumlu görüş belirttiği görülmektedir. Ancak köyde yaşayan yoksul kesim (Romanlar), köydeki konut fiyatlarının yükselmesi nedeniyle konut satın almakta zorlandığı, evlenen çocuğu için köy içerisinde kiralık konut bulamaması nedeniyle memnuniyet durumunu olumsuza çevirdiği görülmektedir.

- "Sahildeki ikinci konutlar köyde geçim sıkıntısına neden olmaktadır" ifadesine $(\bar{X}=2,39)$ katilanların \%18 iken, katılmayanların (geçim sıkıntısı oluşturduğunu düşünmeyenlerin) \%77 gibi yüksek bir oran gösterdiği görülmektedir (Tablo 5). Ancak katılımcıların \%72,1'i "Sahildeki ikinci konutların hayat pahalılı̆̆ına neden olduğunu ( $\bar{X}=3,51)$ düşünmektedir (Tablo 5). Bu durum şu şekilde izah edilebilir: Köy içerisinde kişilerin yaşam şartlarını doğrudan etkilemeyen ikinci konutlar,
Burhaniye ve çevresinde genel anlamda bir hayat pahalılığına neden olduğu düşünülmektedir.

- Yazlıkçılar gelenek ve göreneğimizi değiştirmektedir ifadesine $(\bar{X}=2,52)$ katılımciların \%24,8'i katılırken, \%71,5'i bu ifadeye katılmamaktadır (Tablo 5).

\subsection{Görüşmelere İlişkin Analiz ve Bulgular}

Görüşme yapılan katılımcılara ilişkin bazı temel demografik bilgiler Tablo 6'de sunulmuştur. İkinci konut turizminin kırsal alan üzerindeki etkilerine yönelik yerel halkın görüşleri 3 kategorik başlık (ana tema) altında incelenmiştir: Bunlar: "Toprağın Köylüden Kentliye Geçişi”, "Satılık Köy: Köy Evlerinin Satılması" ve "Kırın Boşalması: Kırdan Kente Göç” temalarıdir.

\section{Kategori 1: Toprağın Köylüden Kentliye Geçişi}

İkinci konut turizminin ev sahibi toplum üzerindeki en büyük etkisi, tarımsal toprağın (zeytinliğin) yerel halkın elinden çıkarak kentli nüfusa geçmesidir. Araştırma alanı kıyılarına yapılan ikinci konutlar ile sahil kenarındaki toprağın kullanımı büyük ölçüde el değiştirmiştir. Diğer bir deyişle, üreticinin elinde olan toprak, tüketicinin eline geçmiştir.

1980 öncesinde başladı buralarda zeytinliklerin satımı. Dışarıdan gelenler sahilden yer aradl, köylü satmaya başladı. ... Ben geçen sene sattım bir zeytinlik, oğlan evlendirdim, 190 bin

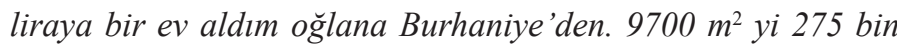
liraya verdim emlakçıya. Benden alan (kişi) 360 bin liraya sattı 20 gün içinde. Benim 275 bin lirayı biriktirme şansım yok. Bir daire aldım, nişan düğ̈̈n yaptım para bitti. Tarımda (çiftçilikte) öyle büyük paralar olmuyor, büyük toprağın da ona göre gideri oluyor (K9). Sahil komple Pelitköy halkınındı. Satıldı satıldı ev yapıldı. Pelitköy'den 100 kişiden 2 kişinin evi var sahilde. Insanlar pişman olsa ne olur, gitti o yerler köylünün elinden, 13 km idi. $13 \mathrm{~km}$ sahil şeridi komple bu yörenin insanının malıydı, şimdi İstanbulluların İmirlilerin (K12).

Tablo 6: Görüşmeye katılan Pelitköy yerel halkına ilişkin bilgiler.

Table 6: Demographic information about local people that were made interview.

\begin{tabular}{|c|c|c|c|c|c|c|c|c|c|}
\hline Kod & Cinsiyet & Yaş & Eğitim & İşi & Kod & Cinsiyet & Yaş & Eğitim & İşi \\
\hline K1 & Erkek & 46 & İlkokul & Çiftçi & K7 & Erkek & 52 & Ortaokul & Çiftçi \\
\hline K2 & Erkek & 43 & Ortaokul & Çiftçi & K8 & Erkek & $65+$ & İlkokul & Emekli \\
\hline K3 & Erkek & $65+$ & İlkokul & Emekli & K9 & Erkek & $65+$ & İlkokul & Emekli \\
\hline K4 & Erkek & 59 & İlkokul & Çiftçi & K10 & Erkek & $65+$ & İlkokul & Emekli \\
\hline K5 & Erkek & 55 & İlkokul & Çiftçi & K11 & Erkek & 40 & Ortaokul & Çiftçi/Muhtar \\
\hline K6 & Erkek & $40+$ & Lise & Çiftçi & K12 & Erkek & $65+$ & illkokul & Emekli \\
\hline
\end{tabular}


Tarımsal toprağın (zeytinliğin) elden çıkmasında, dışarıdan gelenlerin yerel halka yüksek fiyattan satış teklifinde bulunduğu belirtilmektedir. $\mathrm{Bu}$ durum karşısında yerel halkın toprağını elden çıkarmayı cazip teklifler karşısında mantıklı gördüğü ifade edilmektedir.

Köylü yer (zeytinlik) para etmiyor diye sattı. Ucuza almadılar ki (o zamanlar), pahalı aldılar yerleri. Herif 1 parça (zeytinlik) sattı 3 parça (zeytinlik) aldı (başka bir yerden). Kimi bina yaptı, kimi bina aldl parayla, öyle sattılar yani. Kimi de yedi benim gibi. Ben de sattım 5-6 dönüm. ...Oralar (sahil) hep bizim köyündü, sattılar oraları köylü. Hepsi oralar bizimdi. Imar verilince sattılar yani. İ̧mekent'in olduğu yer 17 dönüm yer, kaça aldılar orayı? 1200 liraya aldılar. Ama o günün parastyla iyi paraydl. Ondan sonra sen sattin ben sattım derken, millet birbirinden göre göre satmaya başlad. Kimisi altına araba ald, kimisi parayı pavyonda yedi. Yani perişan ettiler yerleri gittiler, değerlendiremediler (K8). Hoşuna gitti milletin. 10 lira yapmaz bir mala sen 100 lira verirsen, durur mu insanlar. Para geliyor ya, tomarla, saymakla bitiremen. Arazileri sattılar kalmadı ellerinde, şimdi köydeki evlerini de satmaya başladılar. ...Hala satılmaya devam ediyor sahilde zeytinlikler. Şimdi imarsiz (imara girmemiş) yerler (zeytinlikler) de satılmaya başlandi. Alan insanlar Ankara ile irtibatl alyyor. O onu ilerde onu zaten imara sokacak, o hesapla allyor. Onlar Ankara ya bir yazı yazdl $m i$, senin haberin olmadan geçer imar o yerlerden. Bizim gibi bir gariban aldı mı sittin sene imara sokamazsın, tarım toprağ olarak kullanırsin (K10).

Tarımsal toprağın köylüden kentliye geçişi, aslında mekânın kullanım hakkının büyük ölçüde el değiştirmesini beraberinde getirmektedir. Yerel halkın zeytin üretim alanı olan sahil, günümüzde boş zaman ve dinlenme (tüketim) mekânına dönüşmüş ve kentli nüfus tarafından işgal edilmiş durumdadır.

Bunu hep diyoruz, Pelitköylü olarak, bu toprakların sahibi olarak yartn 30-40 sene sonra sahile de inemeyeceğiz yani. Kalmayacak bir yer. Bu şekilde ilerleme olduğu sürece. Yarın bir imar düzenlemesi olursa, bir imara açılırsa tekrar her yer ev olacak. Köylünün bir tane arazisi kalmayacak (K1).

Dışarıdan gelen kentli nüfusun tarımsal toprağın piyasasını yükselttiği, bu nedenle satılan bir toprağın (zeytinliğin) yerel halk tarafından tekrardan geri alınabilmesinin mümkün olmadığı görülmektedir.

Köyde dahi ĕger evin varsa satmışsan, tarlan varsa satmışsan bir daha almak istiyorsan mümkünatı yok. Öbür dünyada ancak alırsın artık. Bir dönüm yer 40 milyar olmuş kardeşim, yer mi alabiliyorsun? Ama bunu kim yükseltmiş bunu, kim yükseltmiş? İstanbullu yükseltmiş. Şu sahilin yol üstlerinden mümkünatı yok yer alamazsın. Giden gitti, nasıl alacaksın geri. ... Pelitköy'den arsa dahi alamazsin 70 milyara. Daha eskiden 5 liraydr. Bir sürü arsa vardl, alan yoktu. İstanbullu alabilir yerlisi alamaz (K4).

\section{Kategori 2: Satılık Köy: Köy Evlerinin Satılması}

Köy içerisindeki bazı münferit konutlar, dışarıdan gelen kent insanları tarafından satın alınmaktadır. Köy evlerinin sahildeki ikinci konut alanlarına göre daha geniş bir alana $\left(\mathrm{m}^{2}\right)$ sahip olmas1, sahil kenarında yer alan ikinci konutlara göre ucuz olması ve sahildeki sitelerde görülen site giderlerinin (aidat, bekçi-bahçıvan giderleri, site içerisi tamir-bakım vb.) köydeki münferit meskenlerde olmaması köy içerisindeki evlere olan talebi artırmaktadır. Ayrıca köyün (Pelitköy) sahile 4 km kadar yakın bir mesafede olması, köyün yüksek yamaçlarından deniz manzarasının izlenebilmesi gibi durumlar, köy evlerine olan talebi artırmaktadır.

Şu an İstanbullulardan köyümüze talep var. Köy daha ucuz olduğu için, merkezde olduğu için, evler taş bina olduğu için talep var. Sahilde ev 250-300 bin burada en baba ev 80-90 bin lira. Güzel, bahçeli, geniş, ferah. Dip dibe komşu yok. Kafanı rahat dinleyebileceğin yer. Suyu ucuz, aidat yok. Site masraflart yok. Deniz manzarası var. Denize uzaklık 3-4 km. vergisi düşük. Ben burayl tercih ederim diyor. Köyde ev alıp da oturan 30-40 hane var şu an. Bunların sekiz dokuzu yll boyu kallyor, geri kalanlar gidip geliyor. (K1). Köyün yarlst yabancllara satıldı. ... Bak şu evler karşıki evler hep satıld y yabancılara. İlerisi için bir yatırım olarak alıyorlar. Burada komisyoncular (emlakçılar) var, evi gösteriyorsun beğeniyor alyyor. Köydeki evini satan adam seviniyor, benim ev 30 lira yapmazken 60 liraya verdim diye. Alan adam da enayiyi kandırdım bedava aldım evi diye seviniyor. Evini satınca hisim akrabanin evinin bir tarafina slğınıyor işte. ...Ş adam köyden bir ev aldı 82 bin liraya, önünde geniş arazisi de var evin, dişarıdan bir yerden böyle bir evi 282 bin liraya alamaz. Sahilde 500-600 lira ev, köyde 150 lira verse üç tane ev alır (K10).

Köy evlerinin dışardan gelen yabancılar tarafından satın alınmasına köy halkı genelde olumlu bakmaktadır. Bu konuda köyde bir tutuculuk, kapalılık bulunmamaktadır. Köy evleri yıkılıp gitmektense satın alınıp oturulması daha iyi olacağı, bu şekilde eski konutların tamir ve bakım görerek ayakta kalacağı ve köyün güzelleşeceği düşünülmektedir (Foto 2, 3). 


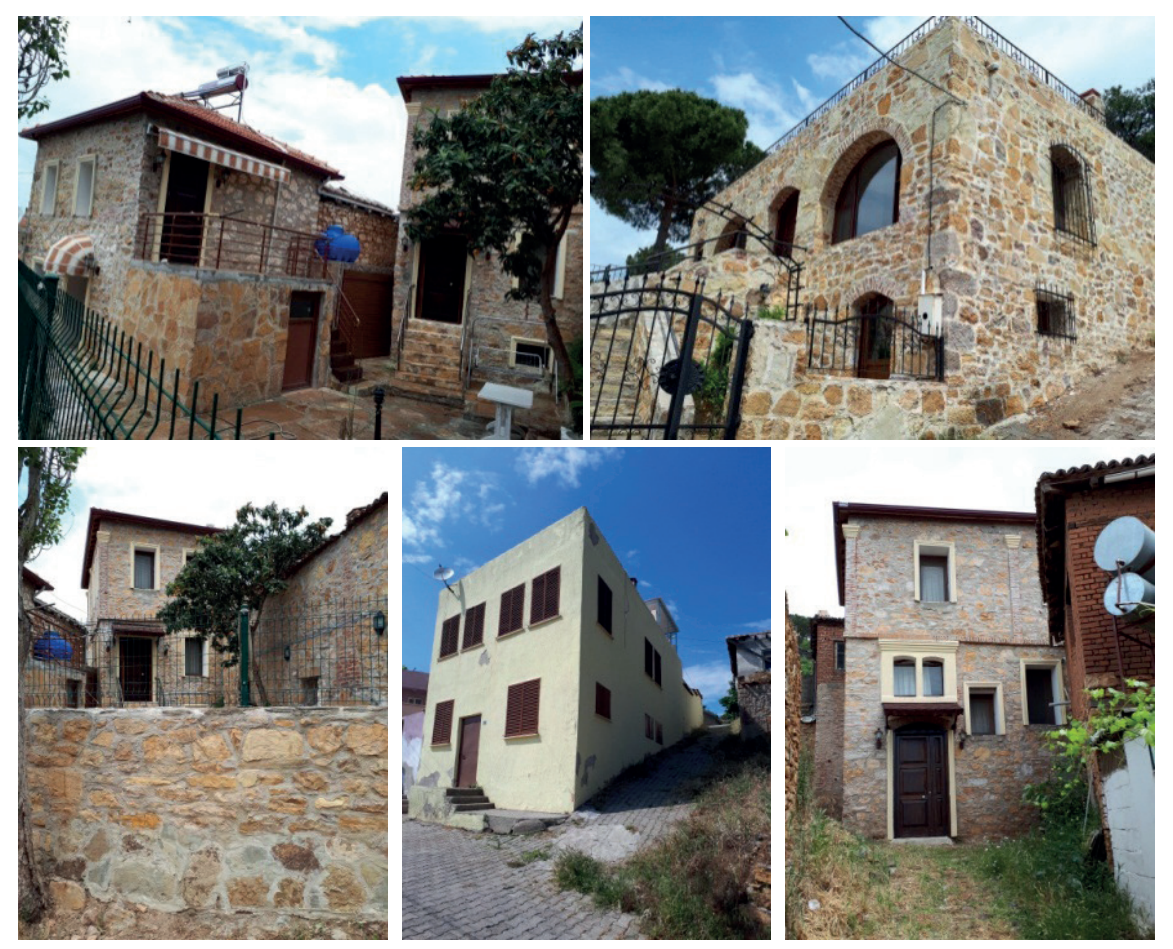

Foto 2: Pelitköy İçerisinde Restore Edilip Kullanılan Bazı İkinci Konutlar. Photo 2: Some second homes which restored and used in the village.

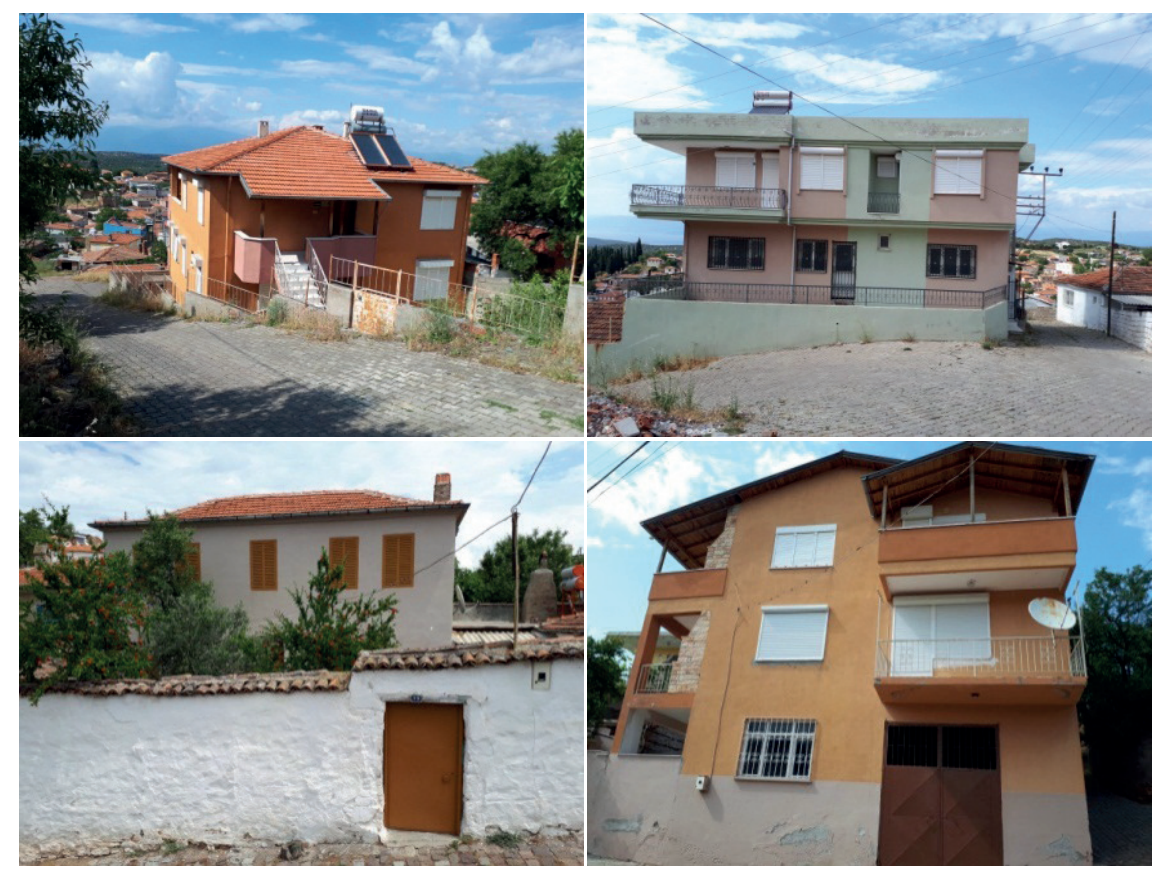

Foto 3: Pelitköy İçerisinde Çok katlı Bazı İkinci Konutlar.

Photo 3: Some second homes which multi-storey in the village.

Dışarıdan gelenler köyden de ev satın alıyor, tadilat yapıyor o da başkasına satıyor. Aldıkları evler zaten kullanılmıyor, viran oluyor dökülüyor. Bir yandan temizlik oluyor köyün içerisinde, evler yenileniyor. (K11). Köydeki evleri satın alarak bir tarihi eseri yaşatıyorlar. Çok masraf yapıyorlar. Şurada bir ev sattılar bana bedava verseler üstüne para verseler içinde yat deseler gidip içine yatmam yani. Ylkalacak evi aldı İstanbullu bir adam bir kuşak beton attı üstüne bir çatı yaptı, şimdi satılı̆̆a çıkardı (K2). Ankara'dan İstanbul'dan gelenler köydeki yıkı dökük evleri altyorlar. O ev ylkılacak harap olacak, o evi alıp düzeltiyor. 
Köyün yerlisi para verip de o evi almaz. Ora yıkılır gider. 30 bin liraya 50 bin liraya ev allyor. Yapılmış bir ev, plan projesine zaten 30-40 bin lira gidiyor. Plan projesi olmadan, gidiyor belediyeden tamir ruhsatı allyor, onu güzelce restore ediyor (K6). Köydeki şu çürük evleri allyorlar tamir ediyorlar. Yabancı olmasa köy evleri 10-15 lira, yabancı alınca 60-70 lira. Yabancı gelince fiyat yükseliyor arz talep olayı yani. Bir amaçla fazla müşteri olursa fiyatı yükseliyor. Yabancı olmasa bizim köy hurdalık olur. Yabancının köye faydası var zararı değil. İlerisini düşündüğ̈̈nde (yabancının köyden konut alması) kötü, ama şu an yarana melhem oluyor, seni şimdi rahatlatyyor. Hasta narkozdan aylkınca ben ne yaptım diyor (K7).

Köy evlerinin satılmasıyla yerel halkın bir kısmı Burhaniye ilçe merkezine göç ederek yeni konutlarda (apartman dairesi) yaşamaya başlamışlardır. Köy evlerinin dışarıdan gelen kentli nüfusa satılması, köy içerisinde konut kira fiyatlarını yükseltmektedir. Köyde evlenen gençlerin köy içerisinde kiralık ev bulmakta güçlük çektikleri, bu nedenle Burhaniye ilçe merkezine göç etmek durumunda kaldıklarını belirtmektedir. Benzer şekilde, köyden bir ev satın almak isteyen bir kişi, artan konut fiyatları nedeniyle konut alma olasılığının düştüğünü ifade etmektedir.

Köyden 50 -100 tane ev satın alınmıştır. Bir iki sene sonra insanlar köyde kiralanacak ev bulamayacak yani. Köylü köydeki evini elinden çıkarlyor, İskele'den ev allyor Öğretmenevleri'nden ev alıyor. İsi düzgünler hep aşağıda İskele'de Öğretmenevleri'nde (K5).

\section{Kategori 3: Kırın Boșalması: Kırdan Kente Göç}

Kırın itici, kentin çekici faktörleri kırın aleyhine işleyerek kırdan kente doğru olan mekânsal hareketliliği hızlandırmaktadır. Kırsal alanlarda üretici pozisyonunu kaybeden ve kırda tutunamayan aileler, kentlerde yeni bir iş yeni bir umut arama arzusu içerisine girmektedirler. Kente olan göçlerle araştırma alanının nüfus kaybetmesinde eğitim ve iş amaçlı göçlerin etkili olduğu görülmektedir. Köyün genç kızlarının evlendiklerinde Burhaniye'deki konutlarda oturmak istemesi, düğün öncesi erkek tarafının kentten konut alma zorunluluğunu ortaya çıkarmaktadır. Kentten daire satın almak için genellikle eldeki bir zeytin bahçesi satışa çıkarılmaktadır. Ayrıca nişan ve düğün için yapılacak harcamalar için elinde nakit parası olmayan aileler, zeytinliklerini satarak çocuklarını evlendirme yoluna gitmektedirler.

Cumhuriyet döneminde bizim köyümüz İngiliz hükümeti gibiydi. Burhaniye bizim köyümüzden fakirdi. O canlı̆̆ın kaybetti. Kimisi çocuğunu okutmak için köyü terk etti. Kimisi beğenmedi terk etti gitti, kimisi lise nerede varsa oraya gitti yerleşti. Hep çocuk meseleleri yani. O yüzden köyümüzün kurucuların hiçbir fert yok şimdi. Nesillerinden çocuklarından yok yani, kendileri öldü gitti zaten de. ...Köylüden hali vakti iyi olanlar İskele Mahallesine, Öğretmenler Mahallesine, Burhaniye'ye taşındılar (K10). Parayı gördü mü adam, satıyor zeytinliği gidip Burhaniye'ye yerleşiyor. Köyün yarısı dışarıdadır (K9).

Tarımın çözülmesi kırdan kopuşu hızlandırmaktadır. Tarımsal üretimin geçim türü şeklinde yapılması, artan tarımsal girdiler sonucu üründen kayda değer oranda tasarruf (kâr) elde edilememesi kentsel alanlara göçü tetiklemektedir. Yeterli sermayesi olan yerel halk ise, Burhaniye ilçe merkezinde kendi iş yerini (emlakçılık, zeytinyağı satış vb.) açarak Pelitköy ile olan günübirlik temasını kestiği görülmektedir.

Parall olanlar Burhaniye'ye gö̧ ediyor. Parall olanlar kaçlyor buradan. İşi olmayan gençler de gidiyor sağa sola, iş arlyor. Çifţ̧ilik bitti yani kalmadı burada. Çiftçilik para etmiyor. Yağ hala 12 lira. Bizden alış 12 lira. Onların eline geçti mi 20 lira. Sana öyle yanslyor. Parayı aracı kazaniyor. Buranin zengini kazanamayinca topraktan fakir oldu. Adam şehire gidiyor kendine bir daire alyyor (K3). Köylünün yüzde 80'i dlşarlda. Köyde işi bile olsa birinin, akşam gidip Burhaniye'deki evinde kalıyor. İs dolayısıyla millet Burhaniye ye yerleşiyor (K11).

Kırsal alanlarda toprağın el değiş̧irmesiyle ortaya çıkan bu durum kırsalda yoksulluğu artırdı̆̆ gibi, yapılan olan göçlerle kırsal yoksulluğun kentlerde devam etmesine neden olmaktadır. İkinci konut turizminin yerel halk üzerindeki etkisi Tablo 7 üzerinden bütüncül olarak düşünüldüğünde, tarımda çözülüş, zeytinliklerin ve köy evlerinin satılması, kırsalda artan yoksulluk ve dışarı olan göçler şeklinde kodlanabilmektedir.

Geçim sıkıntısı, borçlanma ve gündelik hayatın giderleri karşısında ortaya çıkan finansal ihtiyaçlar eldeki toprakların (zeytinliklerin) satışını zorunlu kıldığı görülmektedir. Diğer bir deyişle, küçük tarım işletmecisi olan yerel halkın elde ettiği üründen düşük bir düzeyde ticari gelir (kâr) sağlaması, ancak bu geliri tasarruf edememesi, borçlanmayı kaçınılmaz kılmaktadır. Finansal kredileri ödemek ve düğün-nişan yapmak gibi durumlarda toprağın (zeytinliklerin) satışı kaçınılmaz olmaktadır. $\mathrm{Bu}$ durumda, toprağını satan ve kırda üreticilik niteliğini kaybeden çiftçiler daha da yoksullaşmaktadır. Sonuçta, kırdan kente göç hızlanmakladır. Kente göç edenler köy evlerini dışarıdan gelen yabancılara satarak kırsaldaki son taşınmazını da elinden çıkarmaktadır. 
Tablo 7: İkinci Konut Turizm Bölgesinde Yaşayan Yerel Halka Illişkin Tematik Kodlama.

Table 7: Thematic coding regarding local people, living in second home tourism region.

\begin{tabular}{|c|c|c|c|}
\hline Kategori & Ifade (Açık Kodlama) & Aksiyel Kod & Seçici Kod \\
\hline Toprağın Köylüden Kentliye Geçişi & $\begin{array}{l}\text { Sahil yörenin insanının malıydı, şimdi İstanbulluların } \\
\text { Köylü yer (zeytinlik) para etmiyor diye sattı } \\
\text { Oralar (sahil) hep bizim köyündü } \\
\text { Dışarıdan gelenler sahilden yer aradı } \\
\text { Yeri satan adam binanın içinde bekçilik yapıyor } \\
\text { 30-40 sene sonra sahile de inemeyeceğiz } \\
\text { Köylünün bir tane arazisi kalmayacak }\end{array}$ & $\begin{array}{l}\text { Satış } \\
\text { Köylü } \\
\text { İstanbullu } \\
\text { Sahil } \\
\text { Arazi } \\
\text { Zeytinlik }\end{array}$ & $\begin{array}{l}\text { Köylü sahildeki zeytinliğini } \\
\text { İstanbullulara satarak arazini } \\
\text { kentlilere teslim etti. }\end{array}$ \\
\hline Satılık Köy: Köy Evlerinin Satılması & $\begin{array}{l}\text { Şimdi köydeki evlerini de satmaya başladılar } \\
\text { Köyün yarısı yabancılara satıldı } \\
\text { Dışarıdan gelenler köyden de ev satın alıyor } \\
\text { Bir iki sene sonra insanlar köyde kiralanacak ev bulamayacak } \\
\text { Köylü köydeki evini elinden çıkarıyor } \\
\text { Yabancı olmasa bizim köy hurdalık olur } \\
\text { Yabancının köye faydası var zararı değil }\end{array}$ & $\begin{array}{l}\text { Satmak } \\
\text { Köy evi } \\
\text { Yabancı } \\
\text { Köylü }\end{array}$ & $\begin{array}{l}\text { Köy evleri yabancılara satılarak } \\
\text { köylünün elinden çıkıyor. }\end{array}$ \\
\hline Kırın Boşalması: Kırdan Kente Göç & $\begin{array}{l}\text { Satıyor zeytinliği gidip Burhaniye'ye yerleşiyor } \\
\text { Köyün yarısı dışarıda } \\
\text { Köylü çocuğunu okutmak için köyü terk etti } \\
\text { Lise nerede varsa köylü oraya gitti yerleşti } \\
\text { İş dolayısıyla millet Burhaniye'ye yerleşiyor } \\
\text { Paralı olanlar Burhaniye'ye göç ediyor } \\
\text { İşi olmayan gençler de gidiyor sağa sola } \\
\text { Çiftçilik bitti }\end{array}$ & $\begin{array}{l}\text { Göç } \\
\text { Köy } \\
\text { İş } \\
\text { Okul } \\
\text { Çiftçilik }\end{array}$ & $\begin{array}{l}\text { İş ve okul için köyden dışarı } \\
\text { olan göç çiftçiliği bitirdi. }\end{array}$ \\
\hline
\end{tabular}

\section{TARTIŞMA VE SONUÇ}

$\mathrm{Bu}$ araştırma, kırsal alanların tatil ve dinlenme amaçlı olarak tercih edildiğini ve bu alanlara yönelik artan bir ilgi ve talebin oluştuğunu ortaya koymaktadır. Diğer bir deyişle, ikinci konut turizmi kaynaklı olarak, Pelitköy'deki köy evlerine kentli nüfusun giderek artan bir talebinin olduğu görülmektedir. Bu talep karşısında köy evlerine verilen fiyatların yerel halka cazip geldiği ve köy konutlarının satılmaya başlandığı yapılan anket ve görüşmelerde belirlenmiştir. Satın alınan köy evleri restore edildikten sonra ikinci konut olarak pazarlanarak tekrardan satışa sunulmaktadır. $\mathrm{Bu}$ durum, artan talep karşısında köy evlerinin fiyatlarının aşırı yükselmesine neden olmaktadır. Nitekim katılımcıların büyük bir çoğunluğu $(\bar{X}=4,02)$ "yazlıkçılardan dolayı köy evlerimizin değerinin arttığını" düşünmektedir.

Pelitköy içerisinde yaşayan yoksullar (Romanlar), köy içerisindeki konutların satılması ve bu konutların fiyatının her geçen gün yükselmesi karşısında çaresiz kaldıklarını yapılan görüşmelerde (K17) belirtmektedirler. Köy konutlarının dışardan gelenler tarafindan satın alındığı için, köydeki yoksullar (Romanlar), evlenen çocukları için köy içerisinde kiralık ve satılık konut bulmada güçlük yaşadıklarını, sınırlı sayıdaki köy evlerinin kira fiyatlarının yükselmesi karşısında da ödeme zorluğu çektiklerini ifade etmektedirler. Bu durum karşısında, evlenen gençler köyden kente (Burhaniye vb.) göç ederek yaşadığı topraktan uzaklaşmaktadır. Başka bir deyişle, kentli sınıfin köyden tatil ve dinlenme amaçlı köy evi alması, yerel halkın yerinden olmasına (yerinden edilmesine) neden olmaktadir.

Ankete katılanlardan 55 yaş ve üzeri olanların $(\% 48,4)$ ağırlıklı olması ve \%11,2'sinin ișsiz olması dikkat çekmektedir. Katılımcilardan \%70,2'sinin dönemin asgari ücreti olan 1408 TL'nin altında gelire sahip olması da araştırma alanında yaşayan yerel halkın ekonomik durumu ve satın alma gücü hakkında bir fikir vermektedir. Köy konutlarının kentli nüfusa satılarak el değiştirmesi, bu yoksul kesimin araştırma alanında oluşan emlak piyasasının yükselmesi karşısında kentli nüfus ile rekabet edememesine neden olmaktadır. Bu durum, konut bağlamı üzerinden düşünüldüğünde kırsalda kalıcı yoksulluğu artırmaktadır. Ayrıca katılımcıların büyük bir kısmının $(\bar{X}=3,51)$ "sahildeki ikinci konutların hayat pahalılı̆̆ına neden olduğunu" düşünmesi, konut piyasası dışında, gündelik hayat içerisinde de fiyatların yüksek olmasından yakınıldığı görülmektedir.

Araştırma alanındaki konutlarının İstanbul, Bursa, İzmit ve Sakarya gibi büyük kentlerden gelen kentli nüfusa satılmasını yavaşlatacak yerel politikaların oluşturulması gerekmektedir. Pelitköy'ün düşük gelirli halkının yaşadığı alanda tutunabilmesi için, sosyal politikaların oluşturulması ve bu kesime yönelik uzun vadeli ödeme seçenekleri ile sosyal konutların sağlanması yapılabilir. Böylece yerel halkın kırsalda tutunabilmesi sağlanabilir ve kente göç etmesi yavaşlatılabilir. 
Hakem Değerlendirmesi: Dıș bağımsız.

Çıkar Çatışması: Yazarlar çıkar çatışması bildirmemiştir.

Finansal Destek: Yazarlar bu çalışma için finansal destek almadığını beyan etmiştir.

Teşekkür: Anket ve görüşmelerde yerel halk ile iletişim kurulmasında yardımcı olan Pelitköy muhtarı Hasan VURAL'A ve araştırmanın anket ve görüşmelerine katkı sağlayan Pelitköy yerel halkına teşekkür ederiz.

Peer-review: Externally peer-reviewed.

Conflict of Interest: The authors have no conflict of interest to declare.

Grant Support: The authors declared that this study has received no financial support.

Acknowledgment: We would like to thank Hasan VURAL, the headman of Pelitköy, who helped in establishing communication with the local people in the surveys and interviews, and the local people of Pelitköy who contributed to the surveys and interviews of the research.

\section{KAYNAKÇA/REFERENCES}

Asgary, A., Rezvani, M. R., Mehregan, N. (2011). Local Residents' Preferences for Second Home Tourism Development Policies: A Choice Experiment Analysis, Tourismos: An International Multidisciplinary Journal of Tourism, 6(1), 31-51. http://www. chios.aegean.gr/tourism/vol6iss1.htm

Bakırc1, M. (2007a). Türkiye'de Kırsal Kalkınma: KavramlarPolitikalar-Uygulamalar. Ankara: Nobel Yayınc1lık.

Bakırc1, S. (2007b). Yabancların İkinci Konut Talebinin Fiziksel Çevreye Etkisi: Dalyan Örneği, (Yüksek Lisans Tezi). Gazi Üniversitesi Fen Bilimler Enstitüsü, Ankara.

Birol-Özerk, G. (2012). Türkiye'de Yazlık İkinci Konutların Yarattığı Sorunlar Bağlamında Balıkesir İli Ege Kıyılarındaki Yazlık İkini Konutlara Genel Bir Bakış, MEGARON Balıkesir Mimarlar Odası Balıkesir Şubesi Dergisi, Temmuz 2012, 29-35. https://www. arkitera.com/gorus/turkiyede-yazlik-ikinci-konutlarin-yarattigisorunlar-baglaminda-balikesir-ili-ege-kiyilarindaki-yazlik-ikincikonutlara-genel-bir-bakis/

Coppock, J. T. (1977). Second Homes in Perspective. In J. T. Coppock (Ed.), Second Homes: Curse or Blessing? (pp. 1-16). Oxford: Pergamon Press.

Cottyn, I. (2011). The Spatial and Socio Cultural Impacts of Second Home Development: A Case Study on Franschhoek South Africa. (Master Thesis), Utrecht University International Development Studies, Utrecht.

Çimen, H. (2010). İkinci Konut Satın Almada Destinasyon Kalitesinin Etkisi: Alanya Örneği. (Doktora Tezi). Gazi Üniversitesi Eğitim Bilimleri Enstitüsü, Ankara.

Çubuk, M. (1981). Turizmin Dinlenme Eğlenme ve Boş Zamanları Değerlendirme İle Bütünleşmesi, Yeniden Tanım Denemesi ve Turizm Planlamasında Sistemli Bir Yaklaşım. (Doktora Tezi). MSÜ Mimarlık Fakültesi, İstanbul.

Gallent, N., Mace, A., Tewdwr-Jones, M. (2003). Dispelling a Myth? Second Homes in Rural Wales. AREA. 35(3), 271-284. DOI: 10.1111/1475-4762.00176

Gökeniz, A., Dinç, Y., Taşkır, H. (2010). Türkiye'de İkinci Konut Kavramı ve Ayvalık'ta İkinci Konutlar Üzerinde Yapılan Araştırma Işı̆̆ı̆nda Bir Pazarlama Model Önerisi, O. E. Çolakoğlu (Ed.) 11. Ulusal Turizm Kongresi Bildiriler Kitabı (ss. 848-872), Ankara: Detay Yayıncılık.
Görgülü, T., Manisa, K. (2008). İkinci Konutların Turizm Sektöründe Yeniden Kullanılmasına Yönelik Model, MEGARON YTÜ Mimarlık Fakültesi E-Dergisi, 3(1), 68-78. http://www.journalagent.com/ megaron/pdfs/MEGARON-85856-ARTICLE-MANISA.pdf

Gülcan, M. (2013). Challenges of Coastal Resort Towns Regarding Second Home Developments: The Case of Ayvalık. (Master Thesis). Middle East Technical University, Ankara.

Gülümser, A. A., Baycan Levent, T., Nijkamp, P. (2010). Türkiye'nin Kırsal Yapısı: AB Düzeyinde Bir Karşılaştırma, ITÜDERGISİ, 9(2), 133-144. https://pdfs.semanticscholar.org/2e5b/c6a9c229f022921 81bde8f5f3ed2ae3eb321.pdf

Hall, C. M., Müller, D. K. (2004b). Tourism, Mobility and Second Homes: Between Elite Landscape and Common Ground. Clevedon: Channel View.

Hoogendoorn, G., Visser, G. (2004). Second Homes and Small-Town (Re)Development: The Case of Clarens, Journal of Family Ecology and Consumer Sciences, 32, 105-116. https://pdfs.semanticscholar. org/f554/426b1413fd748f97b0806d2f3c17e4ad6760.pdf

Hoogendoorn, G., Visser, G. (2015). Focusing on the "Blessing" and not the "Curse" of Second Homes: Notes from South Africa, AREA, 1-6: 179-184. DOI: 10.1111/area.12156

Karaaslan, Ş., Yalçıner-Erçoşkun, Ö. (2005). İkinci Konutların Turizme Kazandırılmas1: Antalya/Serik-Boğazkent Örneği, Gazi Üniversitesi Bilimsel Araştırma Projesi, Proje No: 06/2003-81, Gazi Üniversitesi Mimarlık Fakültesi, Şehir ve Bölge Planlama Programı.

Keshavarznia, N., Sarvar, R., Mahdavi, M. (2013). Environmental Impacts of Second Home Development on Damash Village in Gilan Province, Iran, International Journal of Engineering and Advanced Technology (IJEAT), 3(2), 181-184. http://www.ijeat.org/download/ volume-3-issue-2/

Marjavaara, R. (2008). Second Home Tourism. The Root to Displacement in Sweden?, (PhD Dissertation) Department of Social and Economic Geography, Umea University, Sweden.

Marsden, B. (1969). "Holiday Homescapes of Queensland", In J. T. Coppock (Ed.), Second Homes: Curse or Blessing? (pp. 57-73). London: Pergamon Press.

Mizan, G. (1994). Turizm ve İkinci Konut Gelişiminin Doğal Çevre Üzerindeki Etkilerinin Incelenmesi: Dilek Yarımadasi ve Yakın Çevresi Örneği. (Yüksek Lisans Tezi), İTÜ Fen Bilimleri Enstitüsü, İstanbul.

Müller, D. K. (2002). Reinventing the Countryside: German SecondHome Owners in Southern Sweden. Current Issues in Tourism, 5(5), 426-446. https://doi.org/10.4000/remi.1684

Müller, D. K. (2011). Second Homes in Rural Areas: Reflections on a Troubled History. Norsk Geografisk Tidsskrift, 65(3), 137-143. https://doi.org/10.1080/00291951.2011.597872

Müller, D. K., Hoogendoorn, G. (2013). Second Homes: Curse of Blessing? A Review 36 Years Later, Scandinavian Journal of Hospitality and Tourism, 13(4), 353-369. DOI: 10.1080/15022250. 2013.860306

Özgüç, N. (1984). Turizm Coğrafyası. İstanbul: İ.Ü. Yayınları No. 3267, İ.Ü. Edebiyat Fakültesi Yayınları No: 3203. 
Özgüç, N. (2007). Turizm Coğrafyası Özellikler-Bölgeler. İstanbul: Çantay Kitabevi.

Rezavani, M. R. (2003). The Analysis of Formation and Development of Second Homes in Tehran Rural Areas. Researches in Geography, $45,56-69$.

Rye, J. F., Berg, N. G. (2011). The Second Home Phenomenon and Norwegian Rurality. Norwegian Journal of Geography, 65(3), 126136. https://doi.org/10.1016/j.jrurstud.2011.03.005

Tekeli, İ. (2016). Dünyada ve Türkiye'de Kent Kır Karşıtlı̆̆ı Yok Olurken Yerleşmeler Iç̧in Temsil Sorunları ve Strateji Önerileri. Ankara: İdealkent Yayınları.
Urry, J. (2015). Mekânları Tüketmek (Çev: R. G. Öğgül). İstanbul: Ayrıntı Yayınları.

Willams, A. M., Hall, C. M. (2000). Tourism and Migration: New Relationships Between Production and Consumption. Tourism Geographies, 2(1), 5-27. DOI: 10.1080/146166800363420

Willams, A. M., Hall, C. M. (2002). "Tourism, Migration, Circulation and Mobility: The Contingencies of Time and Place”, In C. M. Hall, A. M. Williams ((Eds.), Tourism and Migration: New Releationships Between Production and Consumption (pp. 1-53). Dordrecth, Kluwer. DOI: 10.1007/978-94-017-3554-4_1

Woods, M. (2005). Rural Geography. London: Sage. 
